\title{
PENYIDIKAN IN ABSENTIA DALAM PENANGANAN TINDAK PIDANA KORUPSI DI INDONESIA (SEBUAH ALTERNATIF PENERAPAN ASAS PERADILAN CEPAT) Oleh: Risky Fany Ardhyansah ${ }^{1}$
}

\begin{abstract}
Along with the development of time on examination in the judiciary, in the criminal act of corruption special rules are imposed which stipulate that without the presence of a defendant who has been legally summoned in a court hearing, the trial can continue (in absentia), this is confirmed in Article 38 paragraph (1) Law Number 31 of 1999 concerning the Eradication of Corruption Crime (PTPK Law) as amended by Law Number 20 of 2001. This provision constitutes a deviation from the KUHAP that requires defendants to be present at trial. Based on the formulation of Article 38 paragraph (1) of Law Number 31 of 1999 concerning the Eradication of Criminal Acts of Corruption, the intention without his presence is when he is a defendant or has entered the trial stage. The provision does not formulate and regulate if he is still a suspect or when he is still in the investigation process, then the investigator conducts the investigation process in absentia. This is certainly a legal problem related to the judiciary in absentia during the investigation phase, given the enactment of the judiciary in absentia in the formulation of Article 38 paragraph (1) Law number 31 of 1999 concerning the Eradication of Corruption has a political will from the state to eradicate corruption in Indonesia.

The method used in this study is normative legal research. The source of legal material contained in this study comes from primary, secondary, and tertiary legal materials with data collection techniques based on literature studies and data analysis techniques that use deductive methods.

Based on the results of this study, it is known that Investigators in investigating corruption can carry out investigations in absentia if the suspect is summoned legally and properly, but the absence of the suspect is without a valid reason. The provisions of Article 38 paragraph (1) of the PTPK Law must be interpreted extensively on the meaning of the formulation, because the provision is of the spirit to place corruption as an extraordinary crime whose law enforcement needs to be out of the ordinary as stipulated in the Criminal Procedure Code with the aim of saving that in the judiciary in absentia can also apply at the stage of investigation, not only at the trial stage. Investigations in absentia in cases of corruption can be carried out without violating human rights if the state through law enforcement officials has carried out the obligation to state the reasons for their inability to present suspects. His inability was stated and proven before the court as an objective reason.
\end{abstract}

Keywords: Corruption Crime Investigation, Justice in absentia.

\footnotetext{
${ }^{1}$ Pegawai Kejaksaan Tinggi Lampung
} 


\begin{abstract}
ABSTRAK
Seiring dengan berkembangnya waktu pada pemeriksaan di peradilan, dalam tindak pidana korupsi diberlakukan aturan khusus yang mengatur bahwa tanpa kehadiran terdakwa yang telah dipanggil secara sah di sidang pengadilan, persidangan tetap dapat dilanjutkan (in absentia), hal ini dipertegas dalam Pasal 38 ayat (1) Undang-undang Nomor 31 tahun 1999 tentang Pemberantasan Tindak Pidana Korupsi (UU PTPK) sebagaimana telah diubah dengan Undang-Undang Nomor 20 Tahun 2001. Ketentuan ini merupakan penyimpangan dari KUHAP yang mewajibkan terdakwa hadir di persidangan. Berdasarkan rumusan Pasal 38 ayat (1) Undang-Undang nomor 31 tahun 1999 tentang Pemberantasan Tindak Pidana Korupsi, maksud tanpa kehadirannya itu adalah ketika berstatus sebagai terdakwa atau sudah masuk pada tahap persidangan. Ketentuan tersebut tidak merumuskan dan mengatur jika ia masih berstatus sebagai tersangka atau ketika masih dalam proses penyidikan, kemudian penyidik melakukan proses penyidikan secara in absentia. Hal ini tentu menjadi problematika hukum terkait peradilan in absentia dalam tahap penyidikan, mengingat diberlakukannya peradilan in absentia dalam perumusan Pasal 38 ayat (1) Undang-Undang nomor 31 tahun 1999 tentang Pemberantasan Tindak Pidana Korupsi terkandung suatu keinginan kuat (political wiil) dari negara untuk memberantas tindak pidana korupsi di Indonesia.

Metode yang digunakan dalam penelitian ini adalah penelitian hukum normatif. Sumber bahan hukum yang terdapat dalam penelitian ini berasal dari bahan hukum primer, sekunder, dan tersier dengan teknik pengumpulan data berdasarkan studi kepustakaan dan teknik analisis data yang menggunakan metode deduktif.

Berdasarkan hasil penelitian ini diketahui bahwa Penyidik dalam penyidikan tindak pidana korupsi dapat melakukan penyidikan secara in absentia apabila tersangka setelah dipanggil secara sah dan patut, namun ketidakhadiran tersangka itu tanpa suatu alasan yang sah. Ketentuan Pasal 38 ayat (1) UU PTPK harus ditafsirkan secara ekstensif mengenai makna perumusannya, karena ketentuan tersebut semangatnya adalah menempatkan kejahatan korupsi sebagai kejahatan luar biasa yang penegakan hukumnya pun perlu di luar kebiasaan sebagaimana diatur dalam KUHAP dengan tujuan untuk menyelamatkan kekayaan negara, oleh sebab itu dalam peradilan in absentia dapat berlaku pula pada tahap penyidikan, tidak hanya pada tahap persidangan. Penyidikan in absentia dalam perkara tindak pidana korupsi dapat dilaksanakan tanpa melanggar HAM apabila negara melalui aparat penegak hukum telah menjalankan keharusan mengemukakan alasan-alasan atas ketidakmampuannya menghadirkan tersangka. Ketidakmampuannya itu dikemukakan dan dibuktikan di depan pengadilan sebagai suatu alasan yang obyektif.
\end{abstract}

Kata Kunci: Penyidikan Tindak Pidana Korupsi, Peradilan in absentia.

\section{A. Pendahuluan}

Negara Indonesia adalah negara hukum, pernyataan ini telah secara jelas sebagaimana dirumuskan dalam Pasal 1 ayat (3) Undang-Undang Dasar Negara Republik Indonesia Tahun 1945 (UUD NRI 1945) setelah amandemen. Sebagai negara hukum tentu harus menjunjung tinggi Hak Asasi Manusia (HAM). UUD NRI
1945 merumuskan beberapa pasal tentang HAM, salah satunya adalah Pasal 27 ayat (1), yang merumuskan bahwa segala warga negara bersamaan kedudukannya di dalam hukum dan pemerintahan dan wajib menjunjung hukum dan pemerintahan itu dengan tidak ada kecualinya. Dalam pasal ini terkandung azas persamaan kedudukan dihadapan hukum. 
115 | Jurna | | de a H u kum

Vol. $6 \mathrm{No} .1 \mathrm{M}$ a ret 2020

Magister Hukum Universitas Jenderal Soedirman

Pada dasarnya, penegakan hukum merupakan upaya yang secara sengaja dilakukan untuk mewujudkan cita-cita hukum dalam rangka menciptakan keadilan dan kedamaian dalam kehidupan bermasyarakat, berbangsa dan bernegara. Tegaknya hukum itu dalam arti sempit identik dengan tegaknya Undang-Undang. Akan tetapi, dalam arti luas tegaknya hukum adalah upaya menjamin tegaknya hukum dalam nilai-nilai keadilan dalam masyarakat. Dengan kata lain yang lebih luas lagi, bahwa yang ditegakkan itu hukum dalam suatu sistem, bukan menyangkut peraturan dalam arti formal, tetapi juga institusinya dan bahkan nilai-nilai yang tercermin di dalam masyarakat. ${ }^{2}$

Hukum Acara Pidana merupakan hukum yang memuat peraturan-peraturan untuk melaksanakan hukum pidana, karena hukum acara pidana mempunyai fungsi sebagai alat untuk menyelesaikan segala kepentingan yang berhubungan dengan perbuatan melawan hukum yang diatur dalam hukum pidana. Tujuan hukum acara pidana adalah untuk mencari dan mendapatkan atau setidak-tidaknya mendekati kebenaran materiil, yaitu kebenaran yang selengkap-lengkapnya dari suatu perkara pidana dengan menerapkan ketentuan hukum acara pidana secara jujur dan tepat dengan tujuan untuk mencari siapakah pelaku yang dapat didakwakan melakukan suatu pelanggaran hukum, dan selanjutnya meminta pemeriksaan dan putusan dari pengadilan guna menemukan

2 Jimly Asshiddiqie, 2000, Agenda Pembangunan Hukum Nasional Di Abad Glohalisasi, Sinar Grafika, Jakarta, hlm. 93. apakah terbukti bahwa suatu tindak pidana telah dilakukan dan apakah orang yang didakwa tersebut dapat dipersalahkan.

Pada umumnya dalam perkara pidana menghendaki hadirnya terdakwa dalam pemeriksaan sidang yang bersifat terbuka, seperti yang disebutkan di dalam Pasal 196 ayat (1) KUHAP. Kemudian dalam Pasal 1 sub 15 KUHAP merumuskan bahwa terdakwa adalah seorang tersangka yang dituntut, diperiksa dan diadili di sidang pengadilan. $^{3}$ Dari Pasal 1 sub 15 KUHAP tersebut dapat kita ketahui definisi mengenai terdakwa. Prinsip hadirnya terdakwa dalam perkara pidana ini didasarkan atas hak-hak asasi terdakwa sebagai manusia yang berhak membela diri dan mempertahankan hak-hak kebebasannya, harta benda atau kehormatannya. Dengan demikian, terdakwa memiliki hak dianggap tidak bersalah selama ia belum dijatuhi hukuman yang mempunyai kekuatan hukum tetap oleh Pengadilan, dalam istilah asing disebut "presumption of innocence" (praduga tak bersalah). ${ }^{4}$

Seiring dengan berkembangnya waktu pada pemeriksaan di peradilan, dalam tindak pidana korupsi diberlakukan aturan khusus yang mengatur bahwa tanpa kehadiran terdakwa yang telah dipanggil secara sah di sidang pengadilan, persidangan tetap dapat dilanjutkan (in absentia), hal ini dipertegas dalam Pasal 38 ayat (1) Undang-undang Nomor 31 tahun 1999 tentang Pemberantasan Tindak

\footnotetext{
${ }^{3}$ Djoko Prakoso, 1984, Peradilan In absentia di Indonesia, Ghalia Indonesia, Jakarta, hlm. 53 ${ }^{4}$ lbid., hlm. 55.
} 
Pidana Korupsi (UU PTPK) sebagaimana telah diubah dengan Undang-Undang Nomor 20 Tahun 2001. Ketentuan ini merupakan penyimpangan dari KUHAP yang mewajibkan terdakwa hadir di persidangan.

Berdasarkan rumusan Pasal 38 ayat (1) Undang-undang nomor 31 tahun 1999 tentang Pemberantasan Tindak Pidana Korupsi, maksud tanpa kehadirannya itu adalah ketika berstatus sebagai terdakwa atau sudah masuk pada tahap persidangan. Ketentuan tersebut tidak merumuskan dan mengatur jika ia masih berstatus sebagai tersangka atau ketika masih dalam proses penyidikan, kemudian penyidik melakukan proses penyidikan secara in absentia. Hal ini tentu menjadi problematika hukum, mengingat diberlakukannya peradilan in absentia dalam perumusan Pasal 38 ayat (1) Undang-undang nomor 31 tahun 1999 tentang Pemberantasan Tindak Pidana Korupsi terkandung suatu keinginan kuat (political wiil) dari negara untuk memberantas tindak pidana korupsi di Indonesia.

\section{B Metode Penelitian}

Metode Pendekatan adalah Yuridis Normatif., Spesifikasi Penelitian Preskriptif. Sumber Data yang dipergunakan adalah Bahan Hukum Primer dan Bahan Hukum Sekunder. Metode Pengumpulan Bahan Hukum Inventarisasi dan Studi Kepustakaan. Metode Penyajian Deskriptif sistematis dan logis, dengan Metode Analisa Kualitatif.
C. Hasil Penelitian dan Pembahasan

1. Penyidikan secara in absentia dalam penanganan tindak pidana korupsi

Peraturan hukum pidana harus dijamin pelaksanaannya agar ditaati oleh masyarakat. Hukum pidana yang mengandung norma hukum dan sanksi masyarakat, diterapkan terhadap barang siapa melakukan perbuatan pidana yang dilakukan dengan kesalahan yang dapat merugikan atau membahayakan masyarakat. Hukum pidana tidak dapat dilaksanakan apabila tanpa ada aturan beracara, yaitu proses perkara pidana dan menentukan suatu keputusan dengan menjatuhkan sanksi pidana atau keputusan lain, kepada seseorang yang terbukti atau tidak terbukti melakukan perbuatan pidana dengan kesalahannya. Secara singkat dapat dikatakan bahwa hukum pidana itu dilaksanakan melalui hukum acara pidana. $^{5}$

Bambang Poernomo berpendapat bahwa pihak yang terlibat atau korban dari perbuatan melawan hukum yang diatur dalam hukum pidana harus diselesaikan sesuai dengan aturan permainan yang ditentukan dalam hukum acara pidana, baik mengenai petugas yang diwenangkan dan proses perkara pidananya, maupun perlindungan kepentingan hukum bagi

\footnotetext{
${ }^{5}$ Bambang Poernomo, 1993, Pola Dasar TeoriAsas Umum Hukum Acara Pidana dan Penegakan Hukum Pidana, Liberty, Yogyakarta, hIm. 54.
} 
117 | Jurna | | de a H u kum

Vol. $6 \mathrm{No} .1 \mathrm{M}$ a ret 2020

Magister Hukum Universitas Jenderal Soedirman

masyarakat serta perlindungan hak asasi bagi setiap orang. ${ }^{6}$

Mardjono Reksodiputro menerangkan juga bahwa secara umum sering dikatakan bahwa fungsi dari suatu undang-undang acara pidana adalah untuk membatasi kekuasaan negara dalam bertindak terhadap warga negara masyarakat yang terlibat dalam proses peradilan pidana. Ketentuanketentuan dalam hukum acara pidana melindungi para tersangka dan terdakwa terhadap tindakan aparat penegak hukum dan pengadilan yang melanggar hukum tersebut. Apa yang sering lupa diungkapkan adalah bahwa hukum yang sama memeberikan pula kewenangan-kewenangan tertentu kepada negara melalui aparat penegak hukumnya untuk melakukan tindakantindakan yang dapat melanggar hak asasi warga negaranya. Dengan lain perkataan, hukum acara pidana juga merupakan sumber kewenangan dan kekuasaan bagi berbagai pihak yang terlibat dalam proses ini (polisi, jaksa, hakim dan penasihat hukum). ${ }^{7}$ Hal yang senada juga dikatakan oleh Pompe, seperti yang dikutip oleh Andi Hamzah, menyatakan bahwa hukum pidana formal (hukum acara pidana) mengatur tentang bagaimana negara melalui alat-

\footnotetext{
${ }^{6}$ Bambang Poernomo, 1984, Orientasi Hukum Acara Pidana Indonesia, Amarta Buku, Yogyakarta, hlm. 10.

7 Marjono Reksodiputro, 2007, Hak Asasi Manusia Dalam Sistem Peradilan Pidana., Kumpulan Karangan Buku Ketiga, Pusat pelayanan Keadilan dan Pengabdian Hukum (Lembaga Kriminologi) Universitas Indonesia, Jakarta, hlm.25.
}

alatnya melaksanakan haknya untuk memidana dan menjatuhkan pidana. ${ }^{8}$

Mien Rukmini berpendapat bahwa dalam suatu negara hukum, kekuasaan negara dibatasi dan ditentukan oleh hukum. Demikian pula dengan alat perlengkapan negara dalam melaksanakan tugasnya harus bersumber dan berakar pada hukum. ${ }^{9}$ Hal ini menunjukkan bahwa hukum digambarkan layaknya pedang bermata dua, di mana satu sisi, hukum tersebut dibentuk oleh negara untuk melindungi masyarakat, dan di sisi lain, hukum tersebut juga melindungi masyarakat dari tindakan negara.

KUHAP menata desain prosedur (procedural design) sistem peradilan pidana yang dibagi dalam 3 tahap: ${ }^{10}$
(a) tahap pra-ajudikasi (pre- adjudication);
(b) tahap ajudikasi (adjudication);
(c) tahap purna-ajudikasi (post- adjudication).

Menurut KUHAP, kehadiran tersangka atau terdakwa di setiap tingkat pemeriksaan adalah sangat penting, sebab tugas-tugas dari penegak hukum akan menjadi lebih lancar apabila tersangka atau terdakwa hadir untuk diperiksa. Penegak hukum akan sangat terganggu dan kesulitan

\footnotetext{
8 Andi Hamzah, 2008, Hukum Acara Pidana Indonesia, Sinar Grafika, Jakarta, hlm. 4.

9 Mien Rukmini, 2007, Perlindungan HAM Melalui Asas Pradiga Tidak Bersalah Dan Asas Persamaan Kedudukan Dalam Hukum Pada Sistem Peradilan Pidana, Penerbit Alumni, Bandung, hlm. 22.

${ }_{10}$ Mardjono Reksodiputro, 2007, Hak Asasi Manusia Dalam Sistem Peradilan Pidana. Op. Cit, hlm.33.
} 
dalam menyelesaikan setiap perkara apabila tersangka tidak ditemukan dan tidak hadir dalam pemeriksaan, yang akibatnya akan mengakibatkan membengkaknya jumlah tunggakan perkara. Perkara-perkara yang seharusnya sudah dapat selesai dengan cepat, namun karena tersangka tidak belum ditemukan oleh penyidik mengakibatkan berkas perkara tidak dapat diserahkan ke penuntut umum. Demikian juga dengan terdakwa yang tidak hadir dalam persidangan, akhirnya perkara tersebut harus tertunda karena menunggu sampai hadirnya tersangka di persidangan. Sama halnya juga dengan terpidana yang disidang secara in absentia, jaksa selaku eksekutor tentu akan mengalami kesulitan dalam mengeksekusi pidana denda yang dijatuhkan, yang mengakibatkan tunggakan perkara semaik besar dan bertambahnya kerugian negara akibat denda (piutang negara) yang tidak tertagih.

KUHAP mengatur bahwa kehadiran tersangka adalah hal yang sangat penting dalam proses penyidikan dan penuntutan. Hal ini sebagaimana diatur dalam Pasal 1 butir 2 KUHAP dan Pasal 8 ayat (3) KUHAP. Demikian juga halnya dengan tahap pemeriksaan di pengadilan, KUHAP mengatur tentang pentingnya kehadiran terdakwa dalam acara pemeriksaan biasa. Pada pasal 196 ayat (1) KUHAP disebutkan bahwa pengadilan memutus perkara dengan hadirnya terdakwa kecuali dalam hal undang-undang menentukan lain. Hal ini dipertegas lagi pada Penjelasan Umum KUHAP, yang mengutip asas-asas yang sebelumnya diatur pada UU Kekuasaan Kehakiman yang menyatakan bahwa Pengadilan memeriksa perkara pidana dengan hadirnya terdakwa. Walaupun pada Pasal 214 KUHAP mengatur bahwa ayat (1) jika terdakwa atau wakilnya tidak hadir di sidang, pemeriksaan perkara dilanjutkan, dan ayat (2) Dalam hal putusan diucapkan di luar hadirnya terdakwa, surat amar putusan segera disampaikan kepada terpidana. Ketentuan tersebut tidak berarti bahwa KUHAP memperbolehkan dilakukan pemeriksaan di pengadilan tanpa hadirnya terdakwa, sebab ketentuan Pasal 214 KUHAP ini hanya dikhususkan untuk acara pemeriksaan cepat saja yaitu untuk acara pemeriksaan perkara pelanggaran lalu lintas jalan dan acara pemeriksaan tindak pidana ringan (vide Pasal 205 dan Pasal 211 KUHAP).

Selain pada perkara-perkara pelanggaran lalu lintas dan kejahatan ringan, perundang-undangan kita juga memberi kemungkinan untuk melakukan pemeriksaan dan memutus perkara tanpa hadirnya terdakwa, diantaranya adalah Undang-Undang Darurat Republik Indonesia Nomor 7 Tahun 1955 Tentang Pengusutan, Penuntutan dan Peradilan Tindak Pidana Ekonomi, Undang-Undang Nomor 31 Tahun 1999 Tentang Pemberantasan Tindak Pidana Korupsi sebagaimana telah dirubah dengan Undang-Undang Nomor 20 Tahun 2001 Tentang Perubahan Atas 
Vol. 6 No. 1 M a re t 2020

Magister Hukum Universitas Jenderal Soedirman

Undang-Undang Nomor 31 Tahun 1999

Tentang Pemberantasan Tindak Pidana

Korupsi (UU PTPK), dan Undang-

Undang Nomor 8 Tahun 2010 Tentang

Pencegahan Dan Pemberantasan

Tindak Pidana Pencucian Uang.

Dalam perkara tindak pidana korupsi yang terdakwanya tidak diketahui keberadaannya, akan diminta oleh Penuntut Umum untuk disidangkan secara in absentia (tanpa hadirnya terdakwa). Dalam hal ini, R. Wiyono berpendapat bahwa agar sidang pengadilan dapat dilangsungkan tanpa kehadiran terdakwa, oleh Pasal 38 ayat (1) Undang-Undang Nomor 31 Tahun 1999 ditentukan harus dipenuhi beberapa syarat yaitu (a)Terdakwa telah dipanggil secara sah, (b) Terdakwa tidak hadir di sidang pengadilan tanpa alasan yang sah. Untuk dapat memanggil terdakwa secara sah, Penuntut Umum harus mengikuti beberapa petunjuk sebagaimana dimaksud dalam Pasal 145 dan Pasal 146 ayat (1) KUHAP. ${ }^{11}$

Dalam penjelasan Pasal 38 UU PTPK tersebut dijelaskan bahwa ketentuan tersebut dimaksudkan untuk menyelamatkan kekayaan negara, sehingga tanpa kehadiran terdakwa pun, perkara dapat diperiksa oleh hakim. Oleh karena ketentuan yang diatur pada UU PTPK adalah bersifat khusus, maka disini berlaku azas hukum pidana yaitu lex specialis derogat lex generali, yang artinya bahwa KUHAP

11 R. Wiyono, 2006, Pembahasan UndangUndang Pemberantasan Tindak Pidana Korupsi, Sinar Grafika, Jakarta, hlm. 204. yang merupakan ketentuan hukum acara yang bersifat umum dikesampingkan dengan adanya undang-undang ini. Dengan demikian, ketentuan yang diatur pada pasal 196 ayat (1) KUHAP dikesampingkan oleh ketentuan pada Pasal 38 UU PTPK.

Hal ini juga sejalan dengan ketentuan yang diatur pada Pasal 18 ayat (1) Undang-Undang Kekuasaan Kehakiman yang menentukan bahwa pengadilan memeriksa dan memutus perkara pidana dengan hadirnya terdakwa kecuali apabila undangundang menentukan lain. Dapat ditarik kesimpulan bahwa Undang-Undang Kekuasaan Kehakiman memberi pintu masuk dilakukannya pemeriksaan terhadap terdakwa serta memutus perkara tersebut tanpa dihadiri oleh terdakwa sepanjang ditentukan oleh undang-undang, yang dalam hal ini diatur oleh UU PTPK. Martiman Prodjohamidjojo mengemukakan bahwa, diberikan kemungkinan suatu perkara diperiksa dan diputus tanpa hadirnya terdakwa, asal saja ia telah dipanggil dengan sepatutnya dan sah, akan tetapi ia tidak hadir tanpa alasan yang sah. ${ }^{12}$

Dalam usaha pemberantasan tindak pidana korupsi dan juga tindak pidana lainnya, salah satu hal yang sulit untuk dilakukan adalah menemukan tersangkanya. Saat bukti-bukti dirasa sudah cukup, maka penyidik dapat

12 Martiman Prodjohamidjojo, 1984, Pemberantasan Korupsi: Suatu Komentar, Pradnya Paramita, Jakarta, hlm. 41. 
dengan mudah untuk mengetahui serta menentukan siapa tersangka dalam suatu tindak pidana. Namun untuk menemukan tersangkanya adalah suatu hal yang memiliki kesulitan tersendiri, apalagi bila penyidik tidak mengetahui secara jelas alamat ataupun tempat tinggal dari tersangkanya. Apalagi sampai diketahui bahwa tersangkanya telah melarikan diri hingga tidak diketahui keberadaannya. Hal ini tentunya akan sangat menyulitkan penyidik untuk menuntaskan tugas penyidikannya.

Pada Pasal 1 butir 2 KUHAP merumuskan bahwa, tugas dari penyidik dalam melakukan penyidikan adalah mengumpulkan bukti dan menemukan tersangka. Kata "menemukan" menurut Kamus Besar Bahasa Indonesia artinya adalah mendapatkan sesuatu yang belum ada sebelumnya; mendapatkan atau mendapati. ${ }^{13}$ Akan sangat mudah bagi penyidik untuk menemukan tersangka apabila seseorang tertangkap pada waktu sedang melakukan tindak pidana, atau dengan segera sesudah beberapa saat tindak pidana itu dilakukan. Dalam hal ini, pelaku yang demikian disebut dengan tertangkap tangan, yang diatur pada pasal 1 butir 19 KUHAP. Namun apabila tindak pidana tersebut diketahui oleh penyidik setelah tindak pidana itu selesai dilakukan, maka menjadi tanggungjawab dari penyidik untuk

13 Departemen Pendidikan Nasional-Pusat Bahasa, 2008, Kamus Besar Bahasa Indonesia (Edisi Keempat), PT. Gramedia Pustaka Utama, Jakarta, hlm. 1436. mencari serta menemukan tersangkanya. Sangat jelas dalam KUHAP bahwa penyidik harus menemukan tersangka, bukan hanya sekedar mengetahui dan menentukan siapa tersangka dalam suatu tindak pidana. Penyidik dalam hal menemukan tersangka berarti bahwa penyidik menemukan tersangka secara fisik dan dapat bertatap muka dengan tersangka apabila hendak dilakukan pemeriksaan.

Menemukan tersangka saat penyidikan adalah hal yang sangat penting, selain memang menjadi tugas dari penyidik seperti yang diatur pada Pasal 1 butir 2 KUHAP, kehadiran tersangka juga diperlukan untuk membuat Berita Acara Pemeriksaan Tersangka (vide pasal 75 KUHAP). Apabila penyidikan dianggap sudah selesai, dalam hal penyerahan berkas perkara kepada Penuntut Umum seperti yang diatur pada Pasal 8 ayat (3) huruf $b$, penyidik juga menyerahkan barang bukti dan tanggungjawab atas tersangka.

Menurut Harun M. Husein, dengan memperhatikan rangkaian Pasal 8 dan Pasal 110 KUHAP, maka jelaslah bahwa yang dimaksud dengan hasil penyidikan tersebut adalah berkas perkara, tersangka dan barang bukti. Penyerahan hasil penyidikan tersebut dilakukan dalam 2 (dua) tahap, yakni pada tahap pertama dilakukan penyerahan berkas perkara. Pada tahap 
kedua dilakukan penyerahan secara fisik atas tersangka dan barang bukti. ${ }^{14}$

Setelah berkas penyidikan dinyatakan sudah lengkap oleh penuntut umum, penyidik kemudian menyerahkan barang bukti dan tersangka kepada penuntut umum, di mana setelah penyerahan tersebut, maka berakhirlah tugas dari Penyidik. Namun, apakah undang-undang memperbolehkan penuntut umum untuk menyatakan bahwa penyidikan yang dilakukan oleh penyidik telah selesai, sedangkan penyidik tidak mampu melaksanakan perintah pasal 1 butir 2 KUHAP yang mana penyidik tidak dapat menemukan tersangkanya (penyidikan in absentia). Berdasarkan dari data sebagaimana penulis uraikan dalam hasil penelitian yaitu Berkas Perkara Tindak Pidana Korupsi Nomor BP-01/PIDSUS/12/2015 atasnama tersangka Sunardi Bin Jihad, dalam hal ini telah dilakukan penyidikan in absentia dan telah diputus secara in absentia pula oleh Pengadilan dalam Perkara Nomor 120/Pid.SusTPK/2016/PN.SMG. Dalam hal ini artinya, bahwa penuntut umum tetap menyatakan bahwa berkas perkara yang tanpa disertai dengan ditemukannya tersangka oleh penyidik telah lengkap dan penuntut umum juga menerima berkas perkara tersebut untuk dilimpahkan ke pengadilan walaupun tanpa disertai dengan penyerahan tersangka secara fisik dari penyidik ke

14 Harun M Husein, 1991, Penyidikan dan Penuntutan Dalam Proses Pidana, PT. Rineka Cipta, Jakarta, hlm.198. penuntut umum. Dalam hal ini mengandung arti bahwa penyidik telah melakukan penyidikan in absentia dan Penuntut Umum menerima peralihan tanggungjawab tersangka dari penyidik namun tidak disertai penyerahan secara fisik.

Marwan Effendi berpendapat bahwa mengenai formulasi berkas perkara hasil penyidikan in absentia, tidak berbeda dengan berkas perkara tindak pidana yang lazim selama ini dibuat Penyidik. Letak perbedaannya hanya pada Berita Acara Permintaan Keterangan Tersangka, jika pada berkas perkara hasil penyidikan yang biasa ada keterangan tersangka tertuang dalam Berita Acara Permintaan Keterangan Tersangka, tetapi dalam berkas perkara hasil penyidikan in absentia keterangan tersangka tidak ada. Meskipun keterangan tersangka tidak ada, namun Berita Acara Permintaan Keterangan Tersangka seyogyanya tetap dilampirkan, selain itu wajib memuat identitas tersangka secara lengkap mengacu kepada ketentuan Pasal 143 ayat 2 huruf a KUHAP, yaitu memuat nama lengkap, tempat lahir, umur atau tanggal lahir, jenis kelamin, kebangsaan, tempat tinggal, agama dan pekerjaan tersangka. ${ }^{15}$ Pentingnya identitas ini karena akan dituangkan di dalam dan menjadi syarat formil dari

${ }^{15}$ Marwan Effendy, 2007, Kejaksaan Republik Indonesia, Posisi dan Fungsinya dari Perspektif Hukum, Ghalia Indonesia, Jakarta. hlm. 28. 
sahnya suatu surat dakwaan yang akan diajukan ke depan persidangan. ${ }^{16}$

Ketidakhadiran tersangka tidak memberikan keterangan, oleh penyidik dituangkan pada Berita Acara sebagai catatan, bahwa tersangka telah dipanggil secara patut, tetapi tidak hadir atau dengan kata lain tidak memenuhi panggilan permintaan keterangan. Catatan dimaksud dilengkapi dengan masing-masing nomor dan tanggal surat, alamat yang dituju, nama penerimanya dan relaas dari surat panggilan serta ditutup dengan tanda tangan penyidik yang mendapat perintah untuk melakukan permintaan keterangan. ${ }^{17}$

Meskipun tidak diatur dalam undang-undang mengenai penyidikan in absentia, untuk membuktikan tindakan penyidik telah optimal, dapat dimintakan bantuan ke berbagai pihak untuk turut serta mencari tersangka dan dibuat Daftar Pencarian Orang (DPO). Untuk kelengkapan berkas perkara hasil penyidikan, surat panggilan, relaas, surat permintaan bantuan pencarian tersangka dan DPO dilampirkan dalam berkas perkara menjadi satu kesatuan yang tidak terpisahkan. ${ }^{18}$ Untuk lengkapnya susunan berkas hasil penyidikan in absentia mengacu kepada susunan secara umum disesuaikan dengan kebutuhan berkas perkara menurut Pasal 8, 12, 75, 110, 121 dan 138 KUHAP.

\footnotetext{
${ }^{16} \mathrm{lbid}$.

17 Ibid., hlm.29.

18 Ibid.
}

Berkas perkara hasil penyidikan baru dapat dilimpahkan ke Pengadilan apabila memenuhi kelengkapan formil dan materiil. Kelengkapan formil berkas perkara hasil penyidikan antara lain seperti setiap tindakan yang dituangkan dalam berita acara harus dibuat oleh pejabat yang berwenang (penyidik) atas kekuatan sumpah jabatan dan ditandatangani oleh semua pihak yang terlibat tindakan tersebut, memuat identitas tersangka, saksi atau ahli secara lengkap, surat panggilan yang dilakukan secara patut terhadap tersangka, pelaksanaan upaya paksa (penggeledahan dan penyitaan) sesuai dengan ketentuan hukum acara pidana dan tindakan lain yang dibenarkan undang-undang.

Sedangkan

Kelengkapan materiil antara lain dalam berita acara pemeriksaan saksi, ahli dan tindakan lain tersebut harus memuat perbuatan melawan hukum sesuai dengan pasal dari tindak pidana yang disangkakan, adanya kesalahan yang didukung minimal 2 (dua) alat bukti yang memenuhi unsur pasal yang disangkakan, tempus dan locus delictie. Kelengkapan formil dan materiil ini sangat penting mengingat berkas perkara hasil penyidikan adalah dasar dari substansi surat dakwaan sebagaimana ditentukan oleh Pasal 143 ayat (2) huruf $b$ KUHAP. Jika surat dakwaan tidak memenuhi hal dimaksud, maka surat dakwaan dinyatakan batal demi hukum. ${ }^{19}$

\footnotetext{
${ }^{19}$ Ibid., hlm.31.
} 
Berdasarkan atas hal tersebut, pada dasarnya penyidikan in absentia tidak dirumuskan dalam ketentuan peraturan perundang-undangan, namun hal ini dapat dan memungkinkan untuk dilakukan oleh penyidik. Mengingat tujuan dari adanya peradilan in absentia adalah untuk percepatan proses pengembalian asset negara, oleh karenanya Pasal 38 UU PTPK harus ditafsirkan secara ekstensif. Metode penafsiran ekstensif selalu dimulai dengan tahap memahami Undangundang yang ada kemudian dengan tetap memegang maksud dari pembentuk undang-undang dilakukan perluasan makna pada aturan hukum yang ada. Oleh karena itu penafsiran ekstensif dapat disebut sebagai bagian dari metode penafsiran hukum yang dapat digunakan dalam mengadili perkara pidana. ${ }^{20}$ Penafsiran Ekstensif ini merupakan penafsiran yang melampaui batas-batas yang ditetapkan oleh interpretasi gramatikal. Artinya, diberikan kebebasan untuk melakukan kegiatan penafsiran guna mendapatkan dasar hukum yang jelas dalam mengadili suatu perkara. ${ }^{21}$

Ketentuan Pasal 38 ayat (1) UU PTPK jika ditafsirkan secara ekstensif maka dalam hal tahap penyidikan namun tersangka tidak hadir setelah

20 Hwian Christianto, 2010, Batasan dan Perkembangan Penafsiran Ekstensif dalam Hukum Pidana, Jurnal Pamator, Volume 3 Nomor 2, hlm. 103. Diakses pada tanggal 05 Maret 2019 dari http://infestasi.trunojoyo.ac.id/pamator/article/do wnload/2408/1995.

${ }^{21}$ lbid., hlm.104 dipanggil secara sah dan patut, serta ketidakhadirannya itu tanpa suatu alasan maka penyidik dapat melakukan tindakan penyidikan in absentia. Dalam penyidikan in absentia ini perlu memperhatikan beberapa syarat yaitu (a)Tersangka telah dipanggil secara sah, (b) Tersangka tidak hadir tanpa alasan yang sah.

Menurut pendapat Dwiyanto Prihantoro, dalam perspektif pihak yang mendukung adanya upaya peradilan in absentia menyatakan bahwa, demi alasan pengembalian harta negara dalam perkara tindak pidana korupsi dan pemenuhan keadilan, maka pasalpasal dalam UU PTPK harus diberi nafas dan terobosan. Hal ini secara teoritik dibenarkan dengan alasan melakukan proses penemuan hukum (rechtvinding) atas sebuah kasus yang belum tegas aturannya. Acuan yang dipergunakan pendapat ini adalah Pasal 38 ayat (1) UU PTPK yang semangatnya adalah menempatkan kejahatan korupsi sebagai kejahatan luar biasa yang penegakan hukumnya pun di luar kebiasaan sebagaimana diatur dalam KUHAP sebagai suatu prosedur pengecualian (eksepsionalitas) untuk menyelamatkan kekayaan negara. Pada prinsipnya eksepsionalitas dalam hukum acara merupakan prosedur yang bersifat luar biasa seperti pengesampingan asas non-rektroaktif pada kasus pelanggaran HAM, kewenangan mengesampingkan perkara oleh Jaksa Agung ataupun in absentia. Eksepsionalitas diberlakukan 
pada peradilan in absentia perkara tindak pidana korupsi mengingat kejahatan korupsi senantiasa berkaitan dengan jabatan atau disebut dengan kejahatan okupasi (occupational crime) yaitu kejahatan yang dalam pelaksanaannya mensyaratkan adanya suatu jabatan atau jenis pekerjaan tertentu yang dilindungi undang-undang sehingga setiap pelaku kejahatan okupasi yang tergolong powerfull sulit dijangkau oleh hukum. Karena berkaitan dengan jabatan, maka tindak pidana korupsi sering dikelompokkan sebagai kehajatan kerah putih (white collar crime) sehingga tindak pidana korupsi dalam hal ini dikategorikan sebagai kejahatan yang sangat luar biasa (extra ordinary crime) yang butuh penanganan khusus. $^{22}$

2. Relevansi antara penyidikan in absentia dalam tindak pidana korupsi dengan pemenuhan hak-hak tersangka

KUHAP secara eksplisit telah memberikan perlindungan untuk menghindari perlakuan intimidatif terhadap tersangka atau terdakwa, sebagaimana terdapat di dalam Pasal 52 KUHAP dan penjelasannya yang mengharuskan agar tersangka diperiksa dalam situasi bebas dari rasa takut atau ketakutan. Oleh karena itu, wajib dicegah adanya paksaan atau tekanan terhadap tersangka atau terdakwa. Kalau kita lihat juga dalam Pasal 117 KUHAP

22 Dwiyanto Prihantoro, 2003, Sidang Tanpa Terdakwa, Dilema Peradilan In Absentia dan Hak Asasi Manusia, Pustaka Pelajar, Yogyakarta, hlm.26. yang menyatakan bahwa keterangan tersangka dan/atau saksi kepada penyidik diberikan tanpa tekanan dari siapa pun dan/atau dalam bentuk apa pun. Selain Pasal 52 dan Pasal 117 KUHAP di atas di dalam Pasal 51 ayat (1) KUHAP telah pula menegaskan tentang hak tersangka untuk memberikan keterangan secara bebas kepada penyidik.

Sejalan dengan itu, jika Pasal 51 ayat(I), Pasal 52, dan Pasal 117 KUHAP tersebut dikaitkan dengan prinsip universal tentang hak tersangka untuk tidak menyalahkan dirinya sendiri (non self-incrimination) sebagaimana secara implisit tercermin dalam Pasal 66 KUHAP yang menegaskan bahwa tersangka atau terdakwa tidak dibebani kewajiban pembuktian, serta jika dikaitkan lagi dengan Pasal 189 ayat (3) KUHAP yang menegaskan bahwa keterangan terdakwa hanya dapat dipergunakan bagi dirinya sendiri, maka atas dasar ini penyidik menyadari dan menghormati KUHAP sebagai aturan main dalam proses penegakan hukum pidana pada saat penyidik akan melakukan pemeriksaan terhadap tersangka. Saat penyidikan akan dimulai, tersangka harus benar-benar dalam keadaan bebas dari rasa takut atau bebas dari intimidasi penyidik. Tegasnya, tersangka tersebut harus benar-benar dalam keadaan bebas dari segala tekanan dalam bentuk apa pun baik fisik maupun psikis. 
125 | Jurna | | de a H u ku m

Vol. $6 \mathrm{No} .1 \mathrm{M}$ are t 2020

Magister Hukum Universitas Jenderal Soedirman

Berdasarkan ketentuan mungkin sehingga dapat

Pasal 54 dan 114 KUHAP, sebelum

penyidik mulai melakukan

menemukannya (secara fisik).

Namun, dalam kenyataan

pemeriksaan terhadap seorang

tersangka maka wajib diberitahukan

hak-haknya, bahwa yang

bersangkutan berhak mendapatkan

bantuan hukum dan didampingi oleh

penasihat hukum dalam

pemeriksaannya. Yang dimaksud

dengan mendapatkan bantuan

hukum adalah sebelum tersangka

diperiksa penyidik, tersangka dapat

terlebih dahulu berkonsultasi dengan

penasiha hukumnya. Sedangkan

yang dimaksud didampingi penasihat

hukum, berdasarkan ketentuan Pasal

115 KUHAP adalah penasihat hukum

dalam mendampingi tersangka

dilakukan dengan cara menyaksikan

dan mendengar pemeriksaan yang

dilakukan oleh penyidik. Cara ini

dimaksudkan agar penasihat hukum

mengetahui langsung bahwa dalam

pemeriksaan terhadap diri tersangka,

penyidik betul-betul memerhatikan

hak-hak tersangka.

Permasalahan yang sering

ditemukan dalam proses penyidikan

tindak pidana khususnya tindak

pidana korupsi adalah adanya

seseorang yang telah ditetapkan

sebagai tersangka tidak dapat

diketahui dan ditemukan

keberadaannya, meskipun telah

dipanggil sesuai ketentuan yang

berlaku. Atas keadaan tersebut,

penyidik berusaha mencari dan

menemukan tersangka seoptimal

${ }^{23}$ Marwan Effendy, Op. Cit., hlm.61. seringkali terhadap tersangka yang dicari tidak dapat diketemukan keberadaannya sehingga tidak memungkinkan dibawa dengan upaya paksa melalui penangkapan atau penahanan. Apabila kondisi ini berlanjut sampai pada tahap penuntutan dan pemeriksaan di persidangan, maka Pasal 38 ayat (1) UU PTPK memungkinkan dilaksanakannya peradilan in absentia yaitu perkara tindak pidana korupsi dapat diperiksa dan diputus tanpa hadirnya terdakwa. Peradilan in absentia dimaksud dapat diterapkan kepada pelaku tindak pidana korupsi yang keberadaannya tidak diketahui, padahal sudah dipanggil secara sah atau patut sesuai dengan peraturan perundangundangan yang berlaku dan dilakukan semaksimal mungkin. ${ }^{23}$ Selanjutnya tujuan penerapan peradilan in absentia dalam tindak pidana korupsi dapat diketahui dari penjelasan Pasal 38 ayat (1) UU PTPK yaitu untuk menyelamatkan kekayaan negara. Hak kehadiran terdakwa di muka pengadilan merupakan salah satu dari 10 (sepuluh) asas yang mengatur perlindungan KUHAP terhadap "keluhuran harkat serta martabat 
manusia" sebagaimana terdapat

dalam Penjelasan KUHAP. ${ }^{24}$

Hal ini menunjukkan bahwa

KUHAP dan penjelasannya telah memberikan pedoman bagaimana hak-hak sipil (hak-hak warga negara) dilindungi dalam proses peradilan pidana. Proses peradilan pidana dilaksanakan berlandaskan proses hukum yang adil (due process of law), dimana hak-hak tersangka/terdakwa/terpidana

dilindungi dan dianggap sebagai bagian dari hak-hak warga negara (civil rights) dan karena itu merupakan bagian dari HAM. Peradilan harus menjaga bahwa selalu ada kemungkinan untuk menuntut dan memperolehnya apabila hak-hak tersebut dilanggar. ${ }^{25}$

Peradilan in absentia dalam perkara tindak pidana korupsi cenderung dianggap melanggar HAM dengan alasan: ${ }^{26}$

(1) Hak-hak tersangka/ terdakwa untuk membela diri antara lain sudah diatur dalam Pasal 51 dan 52 KUHAP.

(2) Sesuai dengan Pasal 27 UUD 1945 dimana setiap warga negara di hadapan hukum kedudukannya sama, sehingga walaupun tersangka/terdakwa melarikan diri seharusnya menjadi kewajiban dalam penegakan hukum untuk

\footnotetext{
${ }^{24}$ Mardjono Reksodiputro, Op. Cit., hlm.57.

${ }^{25}$ Ibid.

${ }^{26}$ Marwan Effendy, Op. Cit., hlm.72.
}

$\begin{array}{lr}\text { menghadirkannya } & \text { melalui } \\ \text { kerjasama Interpol atau } & \text { atau } \\ \text { perjanjian ekstradisi } & \text { dapat } \\ \text { tersangka/terdakwa diri karena } & \text { tidak }\end{array}$
segera dikenal, sehingga dalam hal ini aparat hukum perlu berusaha semaksimal mungkin untuk menghadirkannya.

(3) Penerapan peradilan in absentia terhadap pelaku tindak pidana korupsi terkait dengan hak-hak asasi tersangka/ terdakwa sebagai manusia yang berhak membela diri dalam pembelaannya di persidangan, yaitu hak untuk membantah (terhadap barang bukti yang diajukan Jaksa Penuntut Umum, maupun keterangan saksi), dan hak untuk memberikan tanggapan, meskipun terdakwa masih diberikan hak untuk mengajukan upaya hukum banding terhadap putusan pengadilan tanpa kehadirannya, karena selama belum ada putusan/vonis dari hakim, hakhak asasi terdakwa dijamin oleh hukum karena dianggap belum bersalah (asas presumption of innocence).

Pelaksanaan peradilan in absentia memang terlihat seperti melanggar HAM. Namun harus diingat bahwa dalam instrumen hak asasi manusia terdapat 2 (dua) macam sifat mengikat suatu instrumen hak asasi manusia yaitu 
127 | Jurna | | de a H u kum

VoI. 6 No. 1 M a ret 2020

Magister Hukum Universitas Jenderal Soedirman

derogasi (derogable) dan non

derogable. Derogasi adalah

"pengecualian", yaitu suatu

mekanisme di mana suatu negara

menyimpangi tanggung jawabnya

secara hukum karena adanya situasi yang darurat. ${ }^{27}$ Alasan yang diperbolehkan digunakan untuk membuat derogasi adalah keadaan darurat yang esensial dan mengancam kelanjutan hidup suatu negara, ancaman esensial terhadap keamanan negara dan disintegrasi bangsa. ${ }^{28}$

Hal ini diperkuat dengan komitmen pemerintah Indonesia dalam pemberantasan tindak pidana korupsi yang dengan menetapkan korupsi sebagai kejahatan luar biasa (extra ordinary crime). Komitmen pemerintah ini jelas tertuang dalam huruf a pertimbangan UU KPK yang menyatakan:

"Bahwa tindak pidana korupsi yang selama ini terjadi secara meluas, tidak hanya merugikan keuangan negara, tetapi juga telah merupakan pelanggaran terhadap hak-hak sosial dan ekonomi masyarakat secara luas, sehingga tindak pidana korupsi perlu digolongkan sebagai kejahatan yang pemberantasannya harus dilakukan secara luar biasa."

Ketentuan lain sebagaimana diatur dalam Pasal 29 DUHAM menegaskan bahwa pembatasan hak-hak asasi individu dapat

${ }^{27}$ Rhona K.M. Smith, 2008, Hukum Hak Asasi Manusia, Pusat Studi Hak Asasi Manusia (PUSHAM) UII, Yogyakarta, hlm. 41 - 42.

28 Ibid., hlm.42. dibenarkan sepanjang bertujuan untuk melindungi hak-hak asasi yang lebih luas dengan syarat diatur dalam bentuk-bentuk undang-undang. ${ }^{29}$

Berdasarkan hal tersebut di atas, pelaksanaan penyidikan in absentia dalam perkara tindak pidana korupsi dapat dilaksanakan tanpa melanggar HAM apabila negara telah menjalankan keharusan mengemukakan alasan-alasan atas ketidakmampuan negara menghadirkan tersangka. Artinya, ketidakmampuan negara dikemukakan dan dibuktikan di depan pengadilan sebagai suatu alasan yang obyektif. Dalam proses dan prosedur pelaksanaan peradilan in absentia, harus sesuai dengan ketentuan peraturan perundangundangan, terutama berkaitan dengan tata cara melakukan pemanggilan secara layak dan diberitahukan di media massa terhadap tersangka tetapi yang bersangkutan tidak hadir dan tidak menggunakan haknya. ${ }^{30} \mathrm{Hal}$ ini sangat penting karena mengingat syarat mutlak dilaksanakannya peradilan in absentia adalah (1) harus dipanggil terlebih dulu secara sah, dan (2) tidak hadir tanpa alasan yang sah.

Mengenai ketidakhadiran terdakwa dalam persidangan in

29 Romli Atmasasmita, 1996, Sistem Peradilan Pidana Perpekstif Eksistensialisme dan Abolisionisme, Binacipta, Bandung, hlm. 13.

${ }^{30}$ Marwan Effendy, Op.cit., hlm. $71-72$. 
absentia, di satu sisi KUHAP memberikan hak kepada terdakwa untuk menghadiri sidang pengadilan dan hak tersebut merupakan hak utama terdakwa untuk seluasluasnya melakukan pembelaan terhadap dirinya, melakukan perlawanan atau keberatan atas dakwaan Jaksa Penuntut Umum. Bahkan juga diberikan keleluasaan apabila pada waktu persidangan sedang berjalan akan tetapi belum mencapai putusan, terdakwa dapat hadir, maka pada sidang berikutnya pengadilan wajib mendengar dan memeriksa terdakwa. Untuk mencapai tujuan pemeriksaan, persidangan dilakukan dengan mengacu kepada prinsip persidangan yang sederhana, cepat dan murah, tetapi karena pengadilan juga harus memperhatikan hak-hak terdakwa, maka harus dicari keseimbangan antara kepentingan terdakwa dengan kecepatan pemeriksaan yang dituntut dalam suatu perkara, terutama perkara korupsi.

Di sisi lain, terdakwa sendiri secara sengaja memang tidak berkeinginan menggunakan hak yang diberikan KUHAP tersebut. Dalam hal ini berarti terdakwa telah memilih untuk tidak menggunakan haknya untuk membela diri di muka persidangan. Ketidakhadiran terdakwa di pemeriksaan sidang pengadilan tanpa alasan yang sah walaupun telah dilakukan pemanggilan secara sah merupakan upaya terdakwa secara sengaja menghindarkan diri dari pemeriksaan yang berakibat pada kebuntuan proses pemeriksaan. ${ }^{31}$ Dalam konteks ini, hak untuk membela diri di muka persidangan dapat ditunda pemenuhannya dikarenakan kesengajaan/kehendak dari terdakwa yang melarikan diri.

Berdasarkan konstruksi yang demikian itu, maka penyidikan in absentia atau tanpa kehadiran tersangka juga dibenarkan dan tidak melanggar HAM apabila negara telah menjalankan keharusan mengemukakan alasan-alasan atas ketidakmampuan negara menghadirkan tersangka. Artinya, ketidakmampuan negara dikemukakan dan dibuktikan di depan pengadilan sebagai suatu alasan yang obyektif. Selain itu, hal ini juga dapat dikatakan sejalan dengan penerapan asas peradilan cepat kaitannya dengan pengembalian asset keuangan negara dalam tindak pidana korupsi.

\section{Simpulan dan Saran}

\section{a. Simpulan}

1. Penyidik dalam penyidikan tindak pidana korupsi dapat melakukan penyidikan secara in absentia apabila tersangka setelah dipanggil secara sah dan patut, namun ketidakhadiran tersangka itu tanpa suatu alasan yang sah.

31 Ibid., hlm.19. 
Ketentuan Pasal 38 ayat (1) UU

PTPK harus ditafsirkan secara

ekstensif mengenai makna perumusannya, karena ketentuan tersebut semangatnya adalah menempatkan kejahatan korupsi sebagai kejahatan luar biasa yang penegakan hukumnya pun perlu di luar kebiasaan sebagaimana diatur dalam KUHAP dengan tujuan untuk menyelamatkan kekayaan negara, oleh sebab itu dalam peradilan in absentia dapat berlaku pula pada tahap penyidikan, tidak hanya pada tahap persidangan. Pengertian penyidikan menurut Pasal 1 butir 2 KUHAP yaitu serangkaian tindakan penyidik dalam hal dan menurut cara yang diatur dalam undang-undang untuk mencari serta mengumpulkan bukti yang dengan bukti itu membuat terang tentang pidana yang terjadi dan guna menemukan tersangkanya. Namun, apabila penyidik tidak mampu melaksanakan perintah Pasal 1 butir 2 KUHAP yang mana penyidik tidak dapat menemukan tersangkanya maka dapat dilakukan dengan penyidikan in absentia.

2. Penyidikan in absentia dalam perkara tindak pidana korupsi dapat dilaksanakan tanpa melanggar HAM apabila negara melalui aparat penegak hukum telah menjalankan keharusan mengemukakan alasan-alasan atas ketidakmampuannya

menghadirkan tersangka.

Ketidakmampuannya itu dikemukakan dan dibuktikan di depan pengadilan sebagai suatu alasan yang obyektif. Dalam proses dan prosedur pelaksanaan peradilan in absentia, harus sesuai dengan ketentuan peraturan perundang-undangan, terutama berkaitan dengan tata cara melakukan pemanggilan secara layak dan diberitahukan di media massa terhadap tersangka tetapi yang bersangkutan tidak hadir dan tidak menggunakan haknya. Hal ini sangat penting karena mengingat syarat mutlak untuk dilaksanakannya peradilan in absentia menurut ketentuan Pasal 38 ayat (1) UU PTPK adalah tersangka harus dipanggil terlebih dahulu secara sah dan tidak hadir tanpa alasan yang sah.

\section{b. Saran}

Menurut pendapat dan saran penulis, perlu segera dilakukan penyesuaian dan persamaan persepsi ketentuan-ketentuan dalam hukum nasional khususnya ketentuan yang mengatur mengenai peradilan tindak pidana korupsi. Mengingat bahwa tahap penyidikan merupakan salah satu bagian dari suatu sistem peradilan pidana, namun pengaturan mengenai penyidikan in absentia belum terakomodir dalam peraturan 


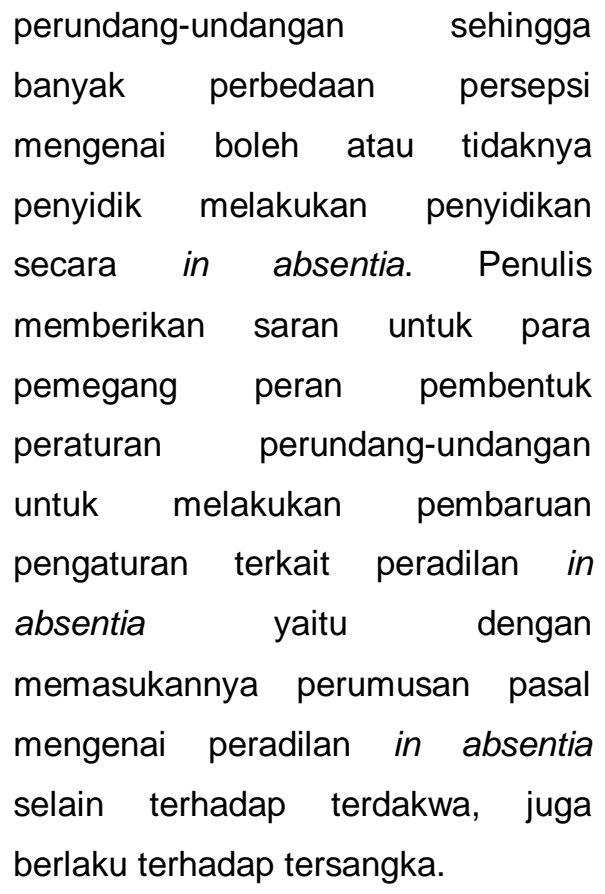

\section{DAFTAR PUSTAKA}

\section{Literatur:}

Atmasasmita, Romli. 1996. Sistem Peradilan Pidana Perpekstif Eksistensialisme dan Abolisionisme. Bandung: Binacipta.

Asshiddiqie, Jimly. 2000. Agenda Pembangunan Hukum Nasional Di Abad Glohalisasi. Jakarta: Sinar Grafika.

Effendy, Marwan. 2007. Kejaksaan Republik Indonesia, Posisi dan Fungsinya dari Perspektif Hukum. Jakarta: Ghalia Indonesia.

Hamzah, Andi. 2008. Hukum Acara Pidana Indonesia. Jakarta: Sinar Grafika.

Husein, Harun M. 1991. Penyidikan dan Penuntutan Dalam Proses Pidana. Jakarta: PT. Rineka Cipta.
Prakoso, Djoko. 1984. Peradilan In absentia di Indonesia. Jakarta: Ghalia Indonesia.

Poernomo, Bambang. 1993. Pola Dasar Teori-Asas Umum Hukum Acara Pidana dan Penegakan Hukum Pidana. Yogyakarta: Liberty.

Poernomo, Bambang. 1984. Orientasi Hukum Acara Pidana Indonesia. Yogyakarta: Amarta Buku.

Prihantoro, Dwiyanto. 2003. Sidang Tanpa Terdakwa, Dilema Peradilan In Absentia dan Hak Asasi Manusia. Yogyakarta: Pustaka Pelajar.

Prodjohamidjojo, Martiman. 1984. Pemberantasan Korupsi: Suatu Komentar. Jakarta: Pradnya Paramita.

Reksodiputro, Marjono. 2007. Hak Asasi Manusia Dalam Sistem Peradilan Pidana. Kumpulan Karangan Buku Ketiga. Jakarta: Pusat pelayanan Keadilan dan Pengabdian Hukum (Lembaga Kriminologi) Universitas Indonesia.

Rukmini, Mien. 2007. Perlindungan HAM Melalui Asas Pradiga Tidak Bersalah Dan Asas Persamaan Kedudukan Dalam Hukum Pada Sistem Peradilan Pidana. Bandung: Penerbit Alumni.

Smith, Rhona K.M. 2008. Hukum Hak Asasi Manusia. Yogyakarta: Pusat Studi Hak Asasi Manusia (PUSHAM) UII.

Wiyono, R. 2006. Pembahasan UndangUndang Pemberantasan Tindak Pidana Korupsi. Jakarta: Sinar Grafika.

Christianto, Hwian. 2010. Batasan dan Perkembangan Penafsiran Ekstensif dalam Hukum Pidana, Jurnal Pamator, Volume 3 Nomor 2, hlm. 103. Diakses pada tanggal 05 Maret 2019 dari http://infestasi.trunojoyo.ac.id/pama tor/article/download/2408/1995.

Departemen Pendidikan Nasional-Pusat Bahasa. 2008. Kamus Besar Bahasa Indonesia (Edisi Keempat). Jakarta: PT. Gramedia Pustaka Utama 